\title{
HERMENEUTIKA GADAMER DALAM STUDI TEOLOGI POLITIK
}

\author{
Faisal Attamimi \\ STAIN Datokarama, Jl. Diponegoro No. 23 Palu \\ E-mail: ical_att@yahoo.com
}

\begin{abstract}
Abstrak: Artikel ini membahas tentang hermeneutika Gadamer dalam studi teologi politik. Pertanyaan tentang makna merupakan jantung studi hermeneutika. Makna atau meaning berasal dari kata bahasa Jerman "meinen" yang artinya "ada di pikiran atau benar". Dengan demikian, makna suatu teks, tindak, hubungan, dan seterusnya adalah apa yang ada di dalam pikiran pengarang dalam melaksanakan atau menghasilkan teks. Menurut hermeneutika gadamer ini, makna tidaklah pernah melibatkan satu unsur pun (agen dan niatnya), namun dua unsur yang harus diinterpretasikan (tindak, teks dan sejenisnya) dan interpreternya. Pandangan Gadamer inilah yang akan digunakan dalam melihat realitas politik, khususnya relasi agama dan negara dalam konteks keindonesiaan.
\end{abstract}

Abstract: This article discusses Gadamer's hermeneutics in the study of political theology. The question of meaning is at the heart of hermeneutic study. The significance or meaning comes from the German word "meinen" which means "in the mind or true". Thus, the meaning of a text, actions, relationships, and so on is what is in the mind of the author in implementing or generating text. According to Gadamer's hermeneutics, the meaning is never involved any of the elements (agents and intentions), but the two elements that must be interpreted (acts, texts and the like) and its interpreter. The Gadamer outlook is what will be used in the view of political realities, particularly the relation between religion and state in the context of Indonesianness.

Kata Kunci: Hermeneutik Gadamer, Politik, teologi, makna, teks, interpreter. 


\section{PENDAHULUAN}

Berbagai sumber filsafat menyebutkan bahwa kata hermeneutik berasal dari kata kerja bahasa Yunani hermenuein yang berarti memahami, menafsirkan, mengartikan atau menerjemahkan. ${ }^{1} \quad$ Dengan melihat asal pengertian ini menunjukkan bahwa hermeneutik sebenarnya sudah dipraktekkan sejak lama. Akan tetapi, nanti pada abad ke 17 baru mulai digunakan untuk menunjukkan teori tentang aturan-aturan yang perlu diikuti dalam proses memahami dan menafsirkan secara tepat terhadap suatu teks yang berasal dari masa lampau, khususnya teks-teks kitab suci dan teks-teks klasik. Selanjutnya dalam filsafat kontemporer term hermeneutik digunakan dalam pengertian yang lebih luas, meliputi hampir semua tema filsafat tradisional, sejauh berkaitan dengan persoalan bahasa. ${ }^{2}$ Sebagai bahasan filsafat dan metode penelitian, hermenutika semakin diminati.

Dalam proses memahami sesuatu yang dilakukan baik berupa teks maupun konteks, akan lahir beragam teori dan metode. Hermenutika adalah salah satu di antara sekian teori dan metode untuk menyingkap makna, sehingga dapat dikatakan bahwa hermeneutika memiliki tanggungjawab utama dalam menyingkap dan menampilkan makna yang ada di balik simbolsimbol yang menjadi obyeknya. ${ }^{3}$

Sebagai sebuah praktek interpretasi dan pemikiran dalam filsafat, hermeneutika sesungguhnya telah muncul sejak awal

${ }^{1}$ Josep Bleicher, Contemporary Hermeneutics: Hermeneutics as Method, Philosophy and Critique (London: Routledge \& Kegan Paul, 1980), 3-4. Lihat pula, Mudjia Rahardjo, Dasar-Dasar Hermeneutika: Antara Intensionalisme dan Gadamerian (Jogjakarta: Ar-Ruzz Media, 2008), 27.

${ }^{2}$ Roger Fowler, A Dictionary of Modern Critical Term (London: Routledge \& Kegan Paul, 1987), 109. Lihat juga Antony Flew. A Dictionary of Philosophy (New York: St Martin's Press, 1984), 146.

${ }^{3}$ Fakhruddin Faiz, Hermenutika Qur'ani: Antara Teks, Konteks, dan Kontekstualisasi (Yogyakarta:Qalam, 2003), 20. 
lahirnya sejarah peradaban manusia. Berbagai peradaban besar yang pernah berkembang sejak dulu pada umumnya memiliki kitab suci yang tentu saja berwujud teks. Karena kitab suci tidak mungkin bisa berbicara sendiri, maka agar bisa diaplikasikan dalam kehidupan nyata, diperlukan pemahaman, pembacaan, penafsiran, dan penafsiran ulang yang pada umumnya dilakukan oleh para ahli agama. Selain itu dapat dipahami juga bahwa terdapat jarak yang panjang antara masa kelahiran teks dan masa penafsiran. Oleh karena itu diperlukan jembatan metodologis untuk memahami teks tersebut. Metodologi itulah salah satunya yang disebut kemudian dengan hermeneutika. Hermeneutika filosofis pertama kali dirintis oleh Friedrich Schleiermacher (1768-1834), kemudian diikuti oleh Wilhem Dilthey (1833-1911), Heidegger (1889-1976), Gadamer, Habermas sampai dengan Paul Ricoeur. ${ }^{4}$

Puncak dari perkembangan aliran filsafat hermeneutika adalah ketika munculnya dua aliran pemikiran yang berlawanan satu dengan yang lain yaitu pragmatika Intensionalisme Hirschian dan hermeneutika Gadamerian. Pragmatika intensionalisme memandang bahwa hakekatnya makna sudah ada karena dibawa oleh pengarang atau penyusun teks, sehingga tinggal menunggu interpretasi penafsir, dan makna berada di belakang teks (behind the text). Sebaliknya, hermeneutika Gadamerian memandang bahwa makna harus dikonstruksi dan direkonstruksi oleh penafsir itu sendiri sesuai konteksnya, sehingga makna berada di depan teks (in front of the text). Hermeneutika Gadamerian mengatakan bahwa makna ditentukan oleh penafsir itu sendiri dengan mempertimbangkan konteks. Dengan demikian konteks merupakan salah satu unsur sangat penting dalam memproduksi makna. Tak bisa dihindari, dua aliran pemikiran yang berbeda tersebut melahirkan pembedaan kerangka metodologis. Walaupun harus diakui bahwa termasuk

${ }^{4}$ E.Sumaryono, Hermeneutik Sebuah Metode Filsafat, cet.III (Yogyakarta: Kanisius, 1993), 35-103 
oleh para pengagasnya bahwa hermeneutika bukan satu-satunya metode yang paling sempurna untuk memahami teks, tetapi hehadirannya telah memberikan sumbangan besar bagi perkembangan pemikiran filsafat kontemporer. ${ }^{5}$

\section{ASAL MULA HERMENEUTIKA}

Hermeneutika berasal dari kata Yunani hermeneuine dan hermenia yang masing-masing berarti "menafsirkan" dan "penafsiran". Dalam bahasa Inggrisnya adalah hermeneutics. Istilah tersebut dalam berbagai bentuknya dapat dibaca dalam sejumlah literatur peninggalan Yunani Kuno, seperti yang digunakan Aristoteles dalam sebuah risalahnya yang berjudul Peri Hermeneias (Tentang Penafsiran). Selain itu, sebagai sebuah terminology, hermeneutika juga bermuatan pandangan hidup (worldview) dari para penggagasnya. ${ }^{6}$

Dalam tradisi Yunani, istilah hermeneutika diasosiasikan dengan Hermes (Hermeios), seorang utusan (dewa) dalam mitologi Yunani Kuno yang bertugas menyampaikan dan menerjemahkan pesan dewa ke dalam bahasa manusia. Di sini terlihat bahwa posisi Hermes sangat penting sebagai penafsir kehendak dan keinginan dewa, sebab jika salah akan berakibat fatal bagi kehidupan.

Ebeling membuat interpretasi yang banyak dikutip mengenai proses penerjemahan yang dilakukan Hermes. Proses tersebut mengandung tiga makna hermeneutis yang mendasar yaitu: 1) mengungkapkan sesuatu yang tadinya masih dalam pikiran melalui kata-kata sebagai medium penyampaian; 2) menjelaskan secara rasional sesuatu yang sebelumnya masih samar-samar sehingga maknanya dapat dimengerti; dan 3) menerjemahkan suatu bahasa yang asing ke dalam bahasa lain

\footnotetext{
${ }^{5}$ Mudjia Rahardjo, Dasar-Dasar Hermeneutika: Antara Intensionalisme \& Gadamerian (Jogjakarta: Ar-Ruzz Media, 2008), 25-26.

${ }^{6}$ Mudjia Rahardjo, Dasar-Dasar Hermeneutika..., 27.
} 
yang lebih dikuasai pembaca. Tiga pengertian tersebut yang terangkum dalam pengertian "menafsirkan" (interpreting, understanding). Hermeneutika sebagai sebuah metode penafsiran, tidak hanya memandang teks tetapi berusaha menyelami kandungan makna literalnya dan berusaha menggali makna dengan mempertimbangkan horizon-horizon yang melingkupi teks tersebut, yaitu horizon pengarang, horizon pembaca, dan horizon teks itu sendiri. ${ }^{7}$

Memahami dengan baik ketiga horizon tersebut penting agar pemahaman dan penafsiran selanjutnya akan menjadi kegiatan rekonstruksi dan reproduksi makna teks. Selain melacak bagaimana satu teks itu dimunculkan oleh pengarangnya dan muatan apa yang masuk dan ingin dimasukkan oleh pengarang ke dalam teks, sebuah aktifitas penafsiran sesungguhnya juga berusaha juga melahirkan kembali makna tersebut sesuai dengan situasi dan kondisi saat teks tersebut dibaca atau dipahami. Komponen pokok dalam kegiatan penafsiran denga metode hermeneutika yakni teks, konteks, dan kontekstualisasi. Keberadaan konteks dan seputar teks tidak bisa dinafikan jika kita ingin memperoleh pemahaman yang tepat terhadap teks. Sebab, kontekslah yang menentukan makna teks, bagaimana teks tersebut harus dibaca, dan seberapa jauh teks tersebut harus dipahami. Dengan demikian, teks yang sama dalam waktu yang sama dapat memiliki makna yang berbeda di mata "penafsir" yang berbeda; bahkan seorang penafsir yang sama dapat memberikan pemahaman teks yang sama secara berbeda-beda ketika ia berada dalam ruang dan waktu yang berbeda. ${ }^{8}$ Ada tiga pemahaman yang dapat diperoleh dari perbincangan hermeneutika yaitu: pertama, hermeneutika dipahami sebagai teknik praksis pemahaman atau penafsiran. Kedua, hermeneutika dipahami sebagai sebuah metode penafsiran. Ketiga, hermeneutika dipahami sebagai filsafat penafsiran.

${ }^{7}$ Mudjia Rahardjo, Dasar-Dasar Hermeneutika..., 28-31.

${ }^{8}$ Mudjia Rahardjo, Dasar-Dasar Hermeneutika..., 32. 
Penafsiran teks dalam perkembangan selanjutnya mencakup masalah penafsiran secara menyeluruh. Tekstualitas yang menjadi arena beroperasinya kerja hermeneutika telah diperluas maknanya, terutama oleh Schleiermacher. Teks tidak lagi merujuk semata pada pengertian teks ajaran agama (kitab suci), tetapi juga mencakup teks-teks lain. Definisi teks dalam pengertian hermenutika lebih lanjut kian meluas, bukan lagi hanya teks tertulis, tetapu juga lisan dan isyarat-isyarat dengan bahasa tubuh. Karena itu, sikap 'diam' seseorang, misalnya, juga bisa dianggap sebagai teks, karena mengundang banyak intertpretasi. ${ }^{9}$

Perkembangan muta'akhir menunjukkan, hermeneutika dipahami sebagai sebuah teori, metodologi, dan praksis penafsiran, yang digerakkan ke arah penangkapan makna dari sebuah teks atau sebuah analog teks, yang secara temporal atau secara kultural berjarak jauh, atau dikaburkan oleh ideology dan kesadaran palsu. ${ }^{10}$ Pada titik ini, hermeneutika lantas beranjak pada pemikiran reflektif dan spekulatif terkait dengan upaya manusia memahami proses penafsiran. Dalam bahasa Gadamer, hermeneutika dipandang sebagai einethorie der wirklichen erfahrung, yaitu suatu usaha filosofis untuk mempertanggungjawabkan pemahaman sebagai proses ontologis dalam manusia. ${ }^{11}$

\section{VARIAN HERMENUTIKA}

Selama ini telah muncul dan berkembang beberapa varian hermeneutika sebagai berikut: pertama, hermeneutika romantis dengan eksemplar Friedrich Ernst Daniel Schleiermacher (1768-

${ }^{9}$ Roy J. Howard, Hermeneutika: Pengantar Teori-Teori Pemahaman Kontemporer: Wacana Analitis, Psikososial, \& Ontologis. (terj. ed), (Bandung: Penerbit Nuansa, 2000), 23. Lihat pula, T. Eagleton, Literary Theory: An Introduction (London: Basil, 1983), 66.

${ }^{10}$ Maulidin, "Sketsa Hermeneutika". Gerbang. No. 14. Volume V., 6.

${ }^{11}$ Fakhruddin Faiz, Hermeneutika Qur'ani: Antara Teks, Konteks dan Kontekstualisasi (Yogyakarta: Qalam, 2003), 34. 
1834), seorang filosof, teolog, filolog, dan tokoh sekaligus pendiri Protestantisme Liberal. Schleiermacher merupakan filosof Jerman pertama yang terus menerus memikirkan persoalan hermeneutika. Itulah sebabnya ia dianggap sebagai bapak hermeneutika modern, karena dalam melieu pemikirannya, makna hermeneutika berubah dari sekadar kajian teologis (teks Bibel) menjadi metode memahami dalam penegertian filsafat.

Pemikiran hermeneutika Schleiermacher bermula dari pertanyaan universal: bagaimana pemahaman manusia dan bagaimana ia terjadi. Dalam hal ini, ia mengajukan dua teori pemahaman hermeneutikanya, yaitu: pemahaman ketatabahasaan (grammatical understanding) terhadap semua ekspresi dan pemahaman psikologis terhadap pengarang. Dari bentuk kedua ini, Schleiermacher lalu mengembangkan apa yang ia sebut intuitive understanding yang operasionalisasinya merupakan suatu kerja rekonstruksi. Artinya, hermeneutika bertugas untuk merekonstruksi pikiran pengarang. Tujuan pemahaman bukan makna yang diperoleh dari dalam materi subjek, tetapi lebih merupakan makna yang muncul dalam pandangan pengarang yang telah direkonstruksi tersebut. Pemahaman yang benar menurut Schleiermacher, tidak saja melibatkan pemahaman konteks kesejarahan dan budaya pengarang, tetapi juga pemahaman terhadap subjektivitas pengarang. ${ }^{12}$

Dalam perspektif ini, ada lima unsur yang terlibat dalam upaya memahami wacana yaitu: penafsir, teks, maksud pengarang, konteks historis, dan konteks kultural. ${ }^{13}$ Penafsir yang hendak memahami suatu wacana selain mencermati teks, juga meletakkannya dalam konteks historis dan kultural, sehingga

\footnotetext{
${ }^{12}$ Hamid Fahmy Zarkasyi, "Menguak Nilai di balik Hermeneutika", ISLAMIA, Th I, No.1/Muharram 1425, 2004, dalam Mudjia Rahardjo, Dasar-Dasar Hermeneutika..., 52.

${ }^{13}$ Anthony Thiselton, New Horizon in Hermeneutics (Michigan:Zondervan Publishing Hause, 1992), 204-205.
} 
menurut Gadamer, ${ }^{14}$ hermeneutika Schleiermacher disebut romantisme historis (historical romanticism). Hanya dengan cara demikian, menurut hermeneutika ini, seorang penafsir benarbenar sampai kepada makna teks. Makna teks, sejauh mengikuti perspektif ini, diidentikkan dengan maksud pengarang. Dengan demikian, bagi Schleiermacher, di samping faktor gramatikal (tata bahasa), faktor kondisi dan motif pengarang sangat penting untuk memahami makna suatu teks.

Kedua, hermeneutika metodis oleh Wilhem Dilthey (18331911). Pemikiran hermeneutika Schleiermacher dikritik oleh Wilhem Dilthey seorang filosof, kritikus sastra dan ahli sejarah dari Jerman. Menurutnya manusia bukan sekadar makhluk berbahasa, seperti yang sangat ditonjolkan oleh Schleiermacher, tetapi makhluk eksistensial. Menurut dilthey, sejak awal manusia tidak pernah hidup hanya sebagai makhluk linguistik yang hanya mendengar, menulis dan membaca untuk kemudian memahami dan menafsirkan. Lebih dari itu, manusia adalah makhluk yang memahami dan menafsirkan dalam setiap aspek kehidupannya. ${ }^{15}$ Namun demikian, dalam proses memahami teks, Dilthey berpandangan bahwa makna teks harus ditelusuri dari maksud subyektif pengarangnya. Bagi Dilthey, hermeneutika adalah "teknik memahami ekspresi tentang kehidupan yang tersusun dalam bentuk tulisan". Oleh karena itu, ia menekankan pada peristiwa dan karya-karya sejarah yang merupakan ekspresi dari pengalaman hidup masa lalu. Untuk memahami pengalaman tersebut, interpreter harus memiliki kesamaan yang intens dengan pengarang. Berbeda dengan Schleiermacher yang memandang bahwa kerja pengarang bersumber dari prinsipprinsip yang implisit dalam pikiran pengarang, Dilthey berpandangan bahwa asumsi seperti itu a historis. Ia

${ }^{14}$ Hans Georg Gadamer, Philosophical Hermeneutics, Translated and Edited by David E. Linge. Berkeley, Los Angeles, (London: University of California, 1977), 7

${ }^{15}$ Maulidin, “Sketsa Hermeneutika”..., 14. 
mempertimbangkan pengaruh eksternal dalam perkembangan pikiran pengarang. Menurut Dilthey, pikiran seseorang selalu berkembang karena situasi eksternal dan pengalamanpengalaman barunya. Karena mengedepankan masa lalu (sejarah) pengarang dalam menafsirkan teks, maka gagasan hermeneutika Dilthey juga sering disebut hermeneutika historis. ${ }^{16}$

Ketiga, Hermeneutika fenomenologis oleh Edmund Husserl (1889-1938). Berbeda dengan hermeneutikawan sebelumnya, Husserl menganggap bahwa pengetahuan dunia obyektif itu bersifat tidak pasti. Menurutnya, apa yang kita andaikan sebagai dunia obyektif sesungguhnya adalah dunia yang sudah diwarnai oleh aparatus sensor yang tak sempurna dari tubuh manusia dan dari aktivitas-aktivitas rasional maupun abstraksi pikiran. Ketika kita berupaya meraih pengetahuan yang pasti tentang "dunia obyektif”, sesungguhnya kita sedang memastikan "dunia persepsi kita-dunia fenomena". ${ }^{17}$

Husserl menawarkan sebuah "ilmu" tentang kesadaran untuk melacak keteraturan sistemik dalam persepsi dan pemahaman melalui kepastian terhadap pengetahuan dunai obyektif yang menjadi niscaya. Melalui fenomenologi, orang harus memiliki keberanian untuk menerima apa yang sebenarnya terlihat dalam fenomena secara tepat, sebagaimana ia menghadirkan dirinya lebih dari pada menafsirkannya, dan kemudian menggambarkannya dengan penuh kejujuran. Karena berangkat dari kerangka dasar fenomenologi, maka menurut hermeneutika Husserl, proses penafsiran harus kembali pada data, bukan pada pemikiran, yakni pada halnya sendiri yang harus menampakkan dirinya. Interpreter harus melepaskan semua pengandaian dan kepercayaan pribadinya serta dengan simpati melihat obyek yang mengarahkan diri kepadanya. Jadi, bagi hermeneutika Husserl, pengetahuan sejati adalah kehadiran

\footnotetext{
${ }^{16}$ Mudjia Rahardjo, Dasar-Dasar Hermeneutika..., 62

${ }^{17}$ Maulidin, "Sketsa Hermeneutika"..., 16-17.
} 
data dalam kesadaran budi, bukan rekayasa pikiran untuk membentuk teori.

Dengan demikian, dalam perspektif ini proses pemahaman yang benar harus mampu membebaskan diri dari prasangka, yakni dengan membiarkan teks "berbicara sendiri". Berbeda dengan hermeneutika romantis (Schleiermacher) dan historis (Dilthey), hermeneutika fenomenologis ini berpendapat bahwa teks merefleksikan kerangka mentalnya sendiri, dan karenanya penafsir harus netral dan menjauhkan diri dari unsur-unsur subyektifnya atas obyek.

Keempat, hermeneutika dialektis oleh Martin Heidegger (1889-1976). Heidegger menentang gagasan fenomenologis Husserl walaupun dia pernah menjadi murid Hausserl. Heidegger menolak gagasan Husserl mengenai netralitas sang penafsir, sebab kerja penafsiran hanya bisa dilakukan dengan didahului prasangka-prasangka mengenai obyek. Menurut Heidegger, prasangka-prasangka historis atas obyek merupakan sumbersumber pemahaman, karena prasangka adalah bagian dari eksistensi yang harus dipahami.

Menurut perpektif ini, pemahaman adalah sesuatu yang muncul dan sudah ada mendahului kognisi. Untuk memahami teks, kita tidak mungkin bisa mencapainya dengan melacak makna tertentu yang ditempatkan di sana oleh pengarang. Keberadaan kita harus dikaitkan dengan apa yang bisa ditunjukkan oleh teks. Implikasinya, tidak ada lagi makna yang tunggal dan tetap; sebaliknya, yang ada adalah keragaman makna dan dinamika eksistensial. Pembacaan atau penafsiran selalu merupakan pembacaan ulang atau penafsiran ulang, yang dengan demikian akan memahami lagi teks yang sama secara baru dengan makna yang baru pula. ${ }^{18}$

\footnotetext{
${ }^{18}$ Mudjia Rahardjo, Dasar-Dasar Hermeneutika..., 65.
} 
Kelima, hermeneutika dialogis oleh Hans Georg Gadamer (1900-2002). Sebagai penerus Heidegger yang telah mengembangkan interpretasi ontologis, Gadamer tidak memaknai hermeneutika sebagai penerjemah eksistensi, tetapi pemikiran dalam tradisi filsafat. Sebenarnya, ia tidak menganggap hermeneutika sebagai metode, karena baginya pemahaman yang benar adalah pemahaman yang mengarah pada tingkat ontologis bukan metodologis. Artinya, kebenaran dapat dicapai bukan melalui metode, tetapi melalui dialektika dengan mengajukan banyak prtanyaan. Dengan demikian, bahasa menjadi medium sangat penting bagi terjadinya dialog. ${ }^{19}$

Menurut perpektif ini, yang akan dibahas lebih lanjut dalam sub bab tersendiri, dalam proses memahami teks, pikiran penafsir juga menceburkan diri ke dalam pembangkitan kembali makna teks. Proses pemahaman adalah proses peleburan horizonhorizon. Tindakan pemahaman adalah suatu kehendak yang sejauh mungkin bisa melahirkan proses peleburan antara sekurang-kurangnya dua horizon. Pengarang dan konteks hostoris dari sebuah teks dipertimbangkan dalam proses interpretative bersama dengan prasangka-prasangka penafsir seperti tradisi, kepentingan praktis, bahasa dan budaya.

Keenam, hermeneutika kritis oleh Jurgen Hambermas. Istilah teori kritis (critical theory) pertama kali dikenalkan oleh Max Horkheimer dan pada mulanya hanya merujuk secara khusus kepada tradisi Mazhab Frankfurt yang di antara tokohnya adalah Max Horkheimer (1895-1973), Theodor W. Adorno (1903-1969), Herbert Marcuse (1898-1979), dan Jurgen Habermas (1929-). Seiring dengan perkembangan ilmu sosial, istilah tersebut mempunyai konotasi yang lebih luas, termasuk di dalam tradisi

\footnotetext{
${ }^{19}$ Hamid Fahmy Zarkasyi, “Menguak Nilai di balik Hermeneutika”,..., 26
} 
teori post-modernisme dan feminism, yang bermazhab tradisi filsafat Prancis. ${ }^{20}$

Dalam karya-karyanya, Habermas tidak pernah membicarakan secara utuh hermeneutika dalam arti definif, baik sebagai sains untuk memahami maupun sebagai sebuah gagasan tunggal. Namun, jika hermeneutika diartikan sebagai cara atau seni memahami makna komunikasi baik yang menggunakan simbol-simbol linguistik maupun non-linguistik, maka Habermas mempunyai gagasan yang unik, yakni bagaimana cara dia memahami. Dianggap unik, karena ia membawa karakter yang khas aliran Frankfurt, yaitu teori kritis. Maka hermeneutika Habermas dapat disebut sebagai hermeneutika kritis. ${ }^{21}$

Menurut perspektif kritis ini, hermeneutika dialogis Gadamer, oleh Habermas dianggap kurang memiliki kesadaran sosial yang kritis. Kalau bagi Gadamer, pemahaman didahului oleh pra-penilaian (pre-judgement), maka bagi Habermas, pemahaman didahului oleh kepentingan. Yang menentukan horizon pemahaman adalah kepentingan sosial (social interest) yang melibatkan kepentingan kekuasaan (power interest) sang interpreter dan khususnya komunitas-komunitas interpreter yang terlibat dalam interpretasi.

Hermeneutika ini lebih mengedepankan refleksi kritis penafsir dan menolak kehadiran prasangka dan tradisi. Karena itu, untuk memahami suatu teks, seorang penafsir harus mampu mengambil jarak atau lemalngkah keluar dari tradisi dan prasangka. Hanya dengan cara demikian hermeneutika mampu mengemban tugas untuk mengembangkan masyarakat komunikatif yang universal.

\footnotetext{
${ }^{20}$ Ben Agger, "Postmodernism: Ideology or Critical Theory", dalam The Discourse of Domination: From Frankfurt School to Postmodernism (Illinois: Northwestern University Press.

${ }^{21}$ Anthony Thiselton, New Horizon in Hermeneutics, ...380
} 
Secara metodologis, hermeneutika kritis Habermas dibangun di atas klaim bahwa setiap bentuk penafsiran dipastikan ada bias-bias dan unsur-unsur kepentingan politik, ekonomi, sosial, termasuk bias stata kelas, suku dan gender. Dengan menggunakan metode ini, konsekuensinya kita harus curiga dan waspada, atau dengan kata lain kritis, terhadap bentuk tafsir atau pengetahuan atau jargon-jargon yang dipakai dalam sains dan agama. $^{22}$

Ketujuh, teori hermeneutika lain yang muncul dari seorang Katolik kelahiran Prancis bernama Paul Ricoeur (1913-). Garis besar teori hermeneutika Ricoeur adalah ia mencoba mencari integrasi dialektis dari dikotomi Dilthey, yaitu penjelasan (explanation) dan pemahaman (understanding). Ricoeur berangkat dari perbedaan fundamental antara paradigm interpretasi teks tertulis dan wacana (discourse) dan percakapan (dialogue). Menurutnya, teks berbeda dengan percakapan, karena ia terlepas dari kondisi asal yang menghasilkannya; niat penulisnya sudah kabur, audiennya lebih umum, dan rerferensinya tidak dapat lagi di deteksi. Konsep utama pandangan Ricoeur adalah bahwa begitu makna obyektif diekspresikan dari niat subyektif sang pengarang, maka berbagai interpretasi yang dapat diterima menjadi mungkin. Makna tidak diambil hanya menurut pandangan hidup pengarang, tetapi juga menurut pengertian pandangan hidup pembacanya. ${ }^{23}$

Kedelapan, hermeneutika dekonstruksionis oleh Jacques Derrida (1930-). Derrida dikenal sebagai salah seorang filosof poststrukturalisme. Terminologinya tentang dekonstruksi merupakan istilah yang sangat kuat untuk menjelaskan gagasan poststrukturalisme. Derrida menunjukkan bahwa bahasa dan juga sitem simbol lainnya, merupakan sesuatu yang tidak stabil. Karena itu maka tulisan (teks), menurut Derrida, selalu

\footnotetext{
${ }^{22}$ Hamid Fahmy Zarkasyi, "Menguak Nilai di balik Hermeneutika",..., 33.
}

${ }^{23}$ Hamid Fahmy Zarkasyi, "Menguak Nilai di balik Hermeneutika",..., 27 
mengalami perubahan, tergantung pada konteks dan pembacanya.

Perspektif ini menolak ambisi untuk menangkap makna esensial yang tunggal dan utuh. Hermeneutika dekonstruksionis menghendaki agar kita lebih menekankan pada pencarian makna makna eksistensial, makna yang di sini dan sekarang. Dekonstruksi Derrida mengingatkan bahwa setiap upaya untuk menemukan makna selalu menyelipkan tuntutan bagi upaya membangun relasi sederhana antara petanda dan penanda. Karena bahasa hanya merujuk pada dirinya sendiri, maka makna adalah arbitrer dan tidak bisa dipastikan begitu saja.

Dari varian tersebut di atas menunjukkan bahwa hermeneutika sebagai aliran filsafat telah mengikuti pandangan hidup tokoh-tokohnya. Tentunya pergeseran makna dan focus kajian masing-masing hermeneutika juga melibatkan pergeseran obyek materi pemahaman, cara dan sikap mental subyek dalam memahami obyek dan juga subyek. Oleh sebab itu, pemilihan hermeneutika sebagai sebuah perpektif dan pendekatan dalam penelitian juga sangat tergantung pada obyek, tujuan, dan metode penlitiannya.

\section{BEBERAPA PENELITIAN YANG MENGGUNAKAN HERMENEUTIKA}

Beberapa karya disertasi dan penelitian yang menggunakan metode hermeneutik adalah sebagai berikut:

Pertama, buku Islam dan Negara: Transformasi Gagasan dan Praktik Politik Islam Indonesia. ${ }^{24}$ Buku ini adalah berasal dari disertasi penulis dalam meraih gelar doktor pada Departemen Ilmu Politik, Ohio State University, Amerika Serikat.

Dalam buku ini digunakan studi pendekatan historis dan hermeneutis. Secara sederhana penulis buku ini menyebut bahwa

${ }^{24}$ Bahtiar Effendy, Islam Dan Negara: Transformasi Gagasan dan Praktik Politik Islam Indonesia, Cet.II (Jakarta: Paramadina, 2009), 17. 
yang dimaksud pendekatan hermeneutis agar dapat menafsirkannya dalam kerangka teori yang digunakan dalam studi. Namun demikian, penulis tidak menguraikan secara detail pendekatan hermeneutika apa yang digunakan.

Kedua, buku Al-Zaitun The Untold Stories: Investigasi terhadap Pesantren Paling Kontroversial di Indonesia. ${ }^{25}$ Buku ini adalah hasil penelitian oleh Indonesian Isntitute for Society Empowerment (INSEP) terhadap pondok pesantren Al-Zaitun yang menjadi polemik soal kemungkinan keterlibatannya dalam NII.

Dalam buku ini, tim penulis menyebutkan dalam penelitian mereka bahwa pendekatan yang digunakan dalam metodologi penelitian bersifat multi-dimensional. Dan untuk meneliti aspek teksnya menggunakan pendekatan hermeneutik. Tidak ada penjelasan lebih lanjut dari pendekatan hermeneutika yang digunakan dalam penelitian mereka kecuali sebatas untuk meneliti aspek teksnya saja. Teks apa yang dimaksud dan hermeneutika perspektif siapa yang dimaksud oleh tim peneliti, tidak dijelaskan secara rinci.

Ketiga, buku Post-Tradisonalisme Islam: Wacana Intelektualisme dalam Komunitas $N U^{26}$ Buku ini merupakan disertasi doktor di UIN Syarif Hidayatullah Jakarta yang kemudian dicetak menjadi buku oleh Balitbang dan Diklat Departemen Agama RI.

Dalam buku tersebut penulis menguraikan dalam metodologi penelitiannya bahwa salah satu pendekatan yang digunakan adalah pendekatan hermeneutika. Pendekatan

\footnotetext{
${ }^{25}$ Tim Peneliti INSEP, Al-Zaitun The Untold Stories: Investigasi terhadap Pesantren Paling Kontroversial di Indonesia, cet.I (Jakarta: Pustaka Alvabet, 2011), 21.

${ }^{26}$ Rumadi, Post-Tradisonalisme Islam: Wacana Intelektualisme dalam Komunitas NU(Jakarta: Balitbang dan Diklat Depag RI, 2008), 10.
} 
hermeneutika dalam arti hermeneutika teks dan hermeneutika sosial dijelaskan secara lengkap oleh penulis buku tersebut.

\section{KELEBIHAN DAN KEKURANGAN METODE HERMENEUTIKA}

Tidak ada metode yang sempurna, itulah kata yang tepat untuk mengambarkan realitas dan berbagai metode yang digunakan dalam penelitian. Demikian pula metode hermeneutik, tentunya di samping mempunyai banyak kelebihan, juga terdapat kelemahan-kelemahan yang selalu ada sebagaimana disampaikan oleh para ahli. Dua kutub pertentangan antara intensionalisme dan hermeneutika Gadamerian, masing-masing memiliki kelemahan. Intensionalisme gagal menjelaskan tentang peran yang dimainkan penafsir dalam menjelaskan gagasan pengarang. Demikian pula hermeneutika Gadamerian tidak mencukupi sebagai teori makna yang dipahami sebagai sesuatu yang utama, karena memandang terlalu berlebihan peran penting intensionalisme atau kemampuan pelaku tindakan dalam menjawab signifikansi suatu tindakan bagi orang lain.

Karena itu, jalan tengahnya adalah intensionalisme perlu dilengkapi dengan menggunakan wawasan dari hermeneutika Gadamerian, dan sebaliknya, hermeneutika Gadamer harus memasukkan wawasan dari intensionalisme untuk memperoleh makna tindak intensional dan signifikansinya.

\section{MEMILIH METODE HERMENEUTIKA GADAMERIAN}

Pertanyaan tentang makna adalah merupakan jantung studi hermeneutika. Makna atau meaning berasal dari kata bahasa Jerman "meinen" yang artinya "ada di pikiran atau benar". Dengan demikian, makna suatu teks, tindak, hubungan, dan seterusnya adalah apa yang ada di dalam pikiran pengarang dalam melaksanakan atau menghasilkan teks. Pengertian ini merupakan dasar bagi teori filsafat umum tentang makna yang disebut "intensionalisme". Menurut intensionalisme, makna suatu tindak atau produknya berasal dari kemauan 
pengarangnya. ${ }^{27}$ Bagi intensionalisme, makna hanya memerlukan agen intensionalisme yang bertindak sengaja agar dihasilkan maknanya. Tidak diperlukan aktivitas lain dan terutama aktivitas interpretasi agar aktivitas itu bermakna. Makna berasal dari aktivitas penciptanya, bukan aktivitas orang lain.

Berbeda dengan intensionalisme, hermeneutika Gadamer, mengatakan bahwa makna suatu tindak (teks atau praktik) bukanlah sesuatu yang ada pada tindak itu sendiri, tetapi makna selalu bermakna bagi seseorang sehingga bersifat relative bagi penafsirnya. Menurut teori ini, makna tidaklah pernah melibatkan satu unsur pun (agen dan niatnya), namun dua unsur yang harus diinterpretasikan (tindak, teks dan sejenisnya) dan interpreternya. Makna muncul dari hubungan antara suatu tindak dengan mereka yang berusaha memahami tindak itu. Makna merupakan produk interaksi antara dua subyek. Dengan demikian, makna perilaku orang lain atau produknya bukanlah apa yang mereka pikirkan, namun apa yang kita atau sebagai interpreter lain pikirkan tentang apa yang telah dilakukan orang lain tersebut.

Hans Georg Gadamer dilahirkan di Marburg-Jerman pada tahun 1900. Ia memiliki latar belakang pendidikan formal dalam bidang studi bahasa dan kebudayaan klasik serta studi filsafat. Gelar Doktor diraihnya ketika berusia 29 tahun dalam bidang filsafat di Merburg. Setelah itu ia menjadi tenaga pengajar di Leipzig pada tahun 1939 dan di Frankfrut pada tahun 1947. Dan akhir karirnya ia menjadi guru besar di Heidelberg. ${ }^{28}$

Pemikiran Gadamer secara umum di latarbelakangi oleh fenomenologi dan bangunan sendi-sendi pemikiran Heidegger. Namun, pemikirannya tentang hermeneutik sebagaimana diakui sendiri oleh Gadamer, secara khusus merupakan inspirasi dari dan reaksi terhadap pemikiran Dilthey dan Schleiermacher dan

${ }^{27}$ Mudjia Rahardjo, Dasar-Dasar Hermeneutika..., 73.

${ }^{28}$ The Cambridge Encyclopedia (Cambridge: Cup Press, 1990), 477 
para pengikut mereka yang dipandang oleh Gadamer terlalu bersifat idealistik. ${ }^{29}$

Hermeneutika Dilthey dan Schleiermacher dapat disimpulkan bahwa untuk memahami suatu teks adalah berupaya menemukan arti yang asli atau menampilkan kembali apa yang dimaksud oleh pengarang yang bersangkutan dari pikiran, pendapat serta visinya. Dengan demikian, bagi keduanya, interpretasi suatu teks merupakan pekerjaan reproduksi. Gadamer tidak sepenuhnya menolak pendapat tersebut, tetapi ia mengemukakan kelemahan hermeneutika romantis dan intensionalisme tersebut dengan mengemjukakan kritikannya. Kritikan pertama adalah menyangkut pendapat mereka bahwa hermeneutika bertugas menemukan arti yang asli dari suatu teks, lalu mencari arti yang oleh si pengarang diletakkan dalam teks itu. Bagi Gadamer, arti suatu teks tetap terbuka dan tidak terbatas pada maksud si pengarang dengan teks tersebut. Menurutnya, interpretasi tidak semata-mata reproduktif tetapi juga produktif. 30

Kritikan kedua menyangkut pendapat hermeneutik romantis tentang waktu. Interpreter tidak mungkin dapat melepaskan diri dari situasi historis dimana ia berada, dank arena itu setiap usaha untuk merekonstruksi zaman si pengarang oleh si pembaca adalah suatu hal yang mustahil dan sia-sia. Karena antar keduanya penuh dengan historisitas yang melingkarinya. Menurut Gadamer, suatu teks tidak terbatas pada masa lampau, tetap memiliki keterbukaan untuk masa kini dan mendatang untuk ditafsirkan menurut cakrawala pemahaman suatu generasi. ${ }^{31}$ Dengan demikian, interpretasi suatu teks merupakan

\footnotetext{
${ }^{29}$ Wasito Poespoprojo, Hermenutika Filsafati: Relevansi dari Beberapa Perspektifnya bagi Kebdayaan Indonesia, disertasi tak diterbitkan, (Bandung: UNPAD, 1985), 92-94. 1975), 264

${ }^{30}$ Hans Georg Gadamer, Truth and Method (New York:Seabury Press,

${ }^{31}$ Hans Georg Gadamer, Truth and Method...264.
} 
tugas yang tidak pernah selesai dan setiap zaman harus mengusahakan interpretasinya sendiri. Karena itu pulalah interpretasi definitive tidak dapat diharapkan.

Dalam pandangan Gadamer, application (penerapan) merupakan suatu unsur yang masuk dalam interpretasi. Understanding (pemahaman), interpretation (penafsiran) dan application (penerapan) merupakan tiga unsur yang tidak bisa dipisahkan satu sama lain. Pemahaman selalu merupakan penafsiran dan penafsiran merupakan penerapan. Menurut Gadamer, undang-undang itu baru dimengerti dengan menerapkannya pada kasus-kasus konkrit. Tidak bisa dikatakan bahwa seorang hakim lebih dahulu sudah mengerti dan menyadari arti ketetapan dalam undang-undang, lalu mnerapkannya pada kasus konkrit. Akan tetapi baru dengan menerapkan ketetapan-ketetapan itu ia melihat dana mengerti isinya, terutama bila penerapan itu menyangkut persoalanpersoalan baru yang belum dikenal ketika undang-undang itu dirumuskan.

Bahasa merupakan isu sentral filsafat hermenutik, karena itu produksi makna baru pada hermeneutik Gadamer berlangsung karena adanya bahasa, sehingga menurut Gadamer tugas utama hermeneutika adalah pemahaman terhadap Being yang ia artikan sebagai bahasa. Pemahaman yang dimaksud Gadamer dalam interelasinya dengan terma hermeneutika adalah Being is Language yang lebih mengarah kepada dialektika searah antara tiga dunia yaitu the world of text, the world of outhor dan the world of reader. Pemahaman berlangsung melalui suatu proses yang melingkar yaitu bertolak dari pra pemahaman tentang realitas yang hendak difahami. Tanpa pra pemahaman ini tidak mungkin dapat diperoleh pemahaman yang sungguh tentang teks tersebut. Proses inilah yang disebut Gadamer sebagai lingkaran hermeneutik. 
Bagi Gadamer setiap pemahaman selalu merupakan sesuatu yang bersifat historik dialektik dan sekaligus merupakan peristiwa kebahasaan. Pemahaman merupakan fusi dari masa lalu dengan masa kini. Menurutnya sejarah adalah sebuah perjalanan tradisi yang ingin membangun visi dan horizon kehidupan di masa depan. Setiap manusia dan setiap generasi adalah anak kandung dan sekaligus pewaris sebuah tradisi. Sebuah tradisi akan berbicara kepada kita ketika secara kritis kita interogasi yang kemudian melahirkan sebuah persahabatan yang diikat oleh keinginan untuk berbagi pengalaman dan gagasan antar generasi dalam rangka membangun peradaban masa depan. ${ }^{32}$

Apa yang diuraikan di atas menjadi alasan bagi penulis untuk memilih metodologi hermeneutik Gadamerian dalam penelitian dengan tema teologi politik. Kompleksitas perpolitikan memungkinkan untuk munculnya interpretasi baru sesuai dengan situasi dan kondisi terkini, aktual dan dinamis.

\section{MODEL OPERASIONAL}

Nation state di Indonesia memiliki keunikan yang khas dengan pilar kebangsaannya untuk dikaji dan diteliti dengan mengunakan interpretasi produktif Gadamer. Dalam dialaktika sejarah bangsa Indonesia dan hubungannya dengan agama serta tarik-menarik kepentingan untuk merumuskan landasan politik kebangsaan dan perdebatan agama dan Negara sampai kemudian ditemukannya komitmen untuk menjadikan empat pilar (UUD'45, Pancasila, Bhinneka Tunggal Ika dan Negara Kesatuan Republik Indonesia). Namun, kenyataannya konsep tersebut masih terus mendapat gugatan sebagian kelompok yang menolak NKRI dan menawarkan konsep yang lain. Namun, sejarah juga telah membuktikan bahwa pasang-surutnya perjalanan bangsa ini dan perkembangan demikian dinamis dari masa ke masa sejak zaman

${ }^{32}$ M. Amin Abdullah, et.al. (ed), Antologi Studi Islam: Teori dan Metodologi ( Yogyakarta: Sunan Kalijaga Press, 2000), 307. 
kemerdekaan sampai zaman reformasi saat ini, komitmen dan reaktualisasi dari nilai-nilai kebangsaan itu tetap dipertahankan dan bahkan semakin kokoh.

Wacana dan dialektika hubungan agama dan Negara dengan konsep nation state di Indonesia dapat dilihat dari realitas dan tradisi politik yang selama ini berkembang di Indonesia akan terus bertahan jika realitas kebangsaan ini senantiasa diinterpretasikan, dinternalisasikan dan disosialisasikan. Jika menggunakan atau merujuk pendekatan hermeneutika Gadamerian maka makna bukan semata apa yang dipikirkan dan dimaksudkan oleh pendiri bangsa ini, tetapi juga apa yang dipahami oleh generasi yang menjadi penerus bangsa ini. Dengan demikian maka konsep pilar kebangsaan yang dirumuskan oleh MPR RI dapat ditelusuri dari perkembangan wacana dan perdebatan yang belum selesai soal hubungan agama dan Negara di Indonesia dewasa ini. Makna ideologi Negara dan falsafah Negara bagi generasi saat ini dapat saja berkembang sesuai dengan dinamika zamannya. Karena itu, menjadi wajar jika era reformasi kemudian muncul berbagai penafsiran seputar dasardasar dan falsafah Negara.

Hermeneutika Gadamerian memandang bahwa makna harus dikonstruksi dan direkonstruksi oleh penafsir itu sendiri sesuai konteksnya, sehingga makna berada di depan teks (in front of the text). Hermeneutika Gadamerian mengatakan bahwa makna ditentukan oleh penafsir itu sendiri dengan mempertimbangkan konteks. Dengan demikian konteks merupakan salah satu unsur sangat penting dalam memproduksi makn. Dengan pendekatan hermeneutika Gadamerian ini, maka apa yang menjadi cita-cita dan harapan para pendiri bangsa Indonesia di masa lalu tidak menjamin akan bisa bertahannya apa yang disebut nation state itu jika tidak terus dimaknai. Yang akan bisa menjamin keberlangsungan NKRI adalah ditentukan oleh pemaknaan generasi saat ini. Pemahaman, interpretasi dan pandangan tokoh-tokoh Islam kontemporer dalam memaknai, 
menafsirkan konsep kebangsaan Indonesia saat ini akan turut menentukan keberlangsungan NKRI sebagai Nation State yang relevan dengan agama-agama di Indonesia.

\section{DAFTAR PUSTAKA}

Abdullah, M. Amin., et.al. (ed), Antologi Studi Islam: Teori dan Metodologi, Yogyakarta: Sunan Kalijaga Press, 2000

Agger, Ben., "Postmodernism: Ideology or Critical Theory", dalam The Discourse of Domination: From Frankfurt School to Postmodernism (Illinois: Northwestern University Press.

Bleicher, Josep., Contemporary Hermeneutics: Hermeneutics as Method, Philosophy and Critique London: Routledge \& Kegan Paul, 1980

Eagleton, T., Literary Theory: An Introduction , London: Basil, 1983

Effendy, Bahtiar., Islam Dan Negara: Transformasi Gagasan dan Praktik Politik Islam Indonesia, Cet.II; Jakarta: Paramadina, 2009

Encyclopedia, The Cambridge, Cambridge: Cup Press, 1990

Fowler, Roger., A Dictionary of Modern Critical Term, London: Routledge \& Kegan Paul, 1987

Flew. Antony., A Dictionary of Philosophy, New York: St Martin's Press, 1984

Faiz, Fakhruddin., Hermenutika Qur'ani: Antara Teks, Konteks, dan Kontekstualisasi, Yogyakarta:Qalam, 2003

Gadamer, Hans Georg., Philosophical Hermeneutics, Translated and Edited by David E. Linge. Berkeley, Los Angeles, London: University of California, 1977

Gadamer, Hans Georg., Truth and Method, New York:Seabury Press, 1975

Howard, Roy J., Hermeneutika: Pengantar Teori-Teori Pemahaman Kontemporer: Wacana Analitis, Psikososial, \& Ontologis. (terj. ed), Bandung: Penerbit Nuansa, 2000

Maulidin, "Sketsa Hermeneutika". Gerbang. No. 14. Volume V., 6. 
Poespoprojo, Wasito., Hermenutika Filsafati: Relevansi dari Beberapa Perspektifnya bagi Kebdayaan Indonesia, disertasi tak diterbitkan, Bandung: UNPAD, 1985

Rahardjo, Mudjia., Dasar-Dasar Hermeneutika: Antara Intensionalisme dan Gadamerian, Jogjakarta: Ar-Ruzz Media, 2008

Rumadi, Post-Tradisonalisme Islam: Wacana Intelektualisme dalam Komunitas NU, Jakarta: Balitbang dan Diklat Depag RI, 2008

Sumaryono, E., Hermeneutik Sebuah Metode Filsafat, cet.III, Yogyakarta: Kanisius, 1993

Thiselton, Anthony, New Horizon in Hermeneutics, Michigan:Zondervan Publishing Hause, 1992

Tim Peneliti INSEP, Al-Zaitun The Untold Stories: Investigasi terhadap Pesantren Paling Kontroversial di Indonesia, cet.I; Jakarta: Pustaka Alvabet, 2011

Zarkasyi, Hamid Fahmy., "Menguak Nilai di balik Hermeneutika", ISLAMIA, Th I, No.1/Muharram 1425, 2004 